\title{
METHODICAL CONTRIBUTIONS FOR THE TRAINING OF THE REPRESENTATIVE BASKETBALL TEAMS AT THE HIGH SCHOOL LEVEL
}

\author{
$\begin{array}{lll}\text { F. COJANU } & 1 & \text { O. NAIBA } \\ & \text { A. CĂTĂNESCU } & \\ & \end{array}$
}

\begin{abstract}
The problems of the theory and practice of the basketball game are multiple and of great complexity, some of them being elucidated through works, researches and observations performed by specialists in the field: teachers, coaches, psychologists, etc. The importance of this theme is given by the characteristics and particularities of this age category, of the high school cycle, because at this age it is acted according to methods and means that aim at consolidating and perfecting the fundamental procedures in the basketball game. In parallel with the activity of consolidating and perfecting the fundamental technical procedures of the basketball game, exercises for a harmonious physical development are also used at this age, using acyclic movements in unbalanced conditions with rapid changes of directions, stops, turns, jumps.
\end{abstract}

Key words: basketball, school, training.

\section{Introduction}

Physical education is "the only subject in the school curriculum that aims to prepare children for a healthy lifestyle and that transmits important social values such as self-discipline, solidarity, team spirit, tolerance and sportsmanship."[5] It is quoted from the report by Mrs Frederique Ries (Belgium - 01.02 2007) on preventing overweight and combating obesity, a report adopted by the European Parliament in 2007.[3]
From the first primary classes the student is bombarded with information from all directions (school, family, media, internet...), about how he should be as an individual, what he should do, what he should know or what is more important to him as man. .[4] Sometimes the school does not insist on information that shows children the importance of exercise on their development, on the biological potential or the influence of physical effort and games in normal psychomotor and biological development. .[6],[8] All these aspects must concern us to develop

\footnotetext{
${ }^{1}$ Department of Physical Education and Sport", University of Pitesti

2 Department of Physical education and special motor skills", Transilvania University of Braşov
} 
in students thinking, practical sense, responsibility, sociability, communication, qualities of will, courage and perseverance, fairness and respect, body aesthetics and morals, qualities necessary for the future European adult, integrated and adapted the requirements of modern education in the European Union. .[7]

Physical education aims at the formation of the modern man through his multilateral development from the physical, intellectual, ethical, aesthetic point of view, in relation to the exigencies of the contemporary and future society, according to the real aptitudes, on the background of which the coordinates of the human personality are outlined; landmarks covering 5 aspects: sanogenesis, motor skills, the background of motor qualities, psychic and attitudinal qualities, specialized knowledge. .[9]

\subsection{The premises of the paper}

The problems of the theory and practice of the basketball game are multiple and of great complexity, some of them being elucidated through works, researches and observations performed by specialists in the field: teachers, coaches, psychologists,etc.[2]

The importance of this theme is given by the characteristics and particularities of this age category, of the high school cycle, because at this age it is acted according to methods and means that aim at consolidating and perfecting the fundamental procedures in the basketball game. .[10]

In parallel with the activity of consolidating and perfecting the fundamental technical procedures of the basketball game, exercises for a harmonious physical development are also used at this age, using acyclic movements in unbalanced conditions with rapid changes of directions, stops, turns, jumps. These exercises are performed under conditions of maneuvering the ball, when it is passed whenever it is in motion but also when the student has the role of passive player. .[10]

The activity of school physical education is carried out based on the regulations and provisions, provided in the documents elaborated by the Ministry of National Education [11].

\subsection{Assumptions and tasks of the paper}

In order to carry out an experimental research that will precede the theoretical substantiation, we propose the following hypotheses:

1.We believe that if we apply effective means of training for the game of basketball in the physical education lesson in high school, then we will be able to improve the technical procedures of basket throwing, dribbling, passing and catching.

2.We believe that if we apply effective means of training for the game of basketball in the physical education lesson in high school, then we will be able to improve the general physical training of children.

Considering the bibliographic research of the basketball game technique, the paper aims to follow a series of tasks, necessary for the development of our study. Through the system of its exercises and depending on the goal pursued, basketball is both a means of physical education and a sport - a sport.

\section{Tasks of the paper:}

1. Discovering and structuring bibliographic materials that study the issues addressed in our research.

2. Highlighting the specific means of learning the technique of basketball game in high school students. 
3. Applying specific means to improve the technique of the basketball game at the level of the high school cycle.

4. Applying specific means to improve the general physical training of children in high school, by educating psychomotor qualities.

\section{The purpose of the paper}

The aim of the paper is the way in which the means specific to the basketball game technique are effectively applied during the physical education class at the high school cycle for the development of birding, catching, basketing and dribbling procedures.

\section{Material and Methods}

As research methods involved in our research we can emphasize that some methods, in relation to others, receive certain priorities. Many of these methods are found in other sciences, but this does not mean that they have not been adapted by the content and theme of their use, to the specifics of physical education and sports.

- Bibliographic study method

- Observation method

- Statistical-mathematical method

- Experiment method

- Graphic method

\section{Research organization}

In order to achieve the proposed goal in relation to the approached topic, we have set up a plan that captures the stages of realization of the concrete operational approach.

The materialization of this staging is presented through a centralized table for what was proposed and of course for what was achieved, as a constituent part of the content of the topic addressed, but also of the temporal structure.

In order to carry out our study as efficiently as possible, the stages that were covered in our documentation were established from the very beginning:

1. December 2017 - April 2018: Bibliographic documentation regarding the theoretical substantiation of the paper.

2. April 2018: Statement of the premises that generate the purpose and hypotheses of the paper.

3. April 2018: Establishing the goal, assumptions and achievable tasks.

4. May-September 2018: Determining the drive technology proposed to be used.

5. September 2018 - February 2019: Carrying out the actual experiment.

6. February-May 2019: Analysis and interpretation of research results.

7.May 2019: Formulation of the conclusions and proposals of the paper.

\section{MODEL OF PREPARATION OF SCHOOL REPRESENTATIVE TEAMS \\ ORGANIZATION OF THE PREPARATION PROCESS}

According to the structure of the school year, and the competitive system, the trainings will take place during school daily, in the gym and outdoors. The duration of the training will be $90-120$ min. During the holidays, if possible, 1-2 centralized training camps will be held.

\section{TRAINING VOLUME}

Number of weeks: 48

Number of workouts / week:

a) on vacation: 7 - 9 workouts $\times 90-120 \%$ week

b) during school: $5 \times 120 \%$ week

c) 1 - 2 camps $x 12$ days, 18 - 20 hours / week

Total number of trainings / year: 580 - 600 hours 


\section{COMPETITIVE ACTIVITY}

- check games: 10 - 12

- official friendly games (event cups): 10 - 12

- international games 8 - 10

- official games: 20 - 25

Total games: 55 - 60 games

\section{WEIGHT OF TRAINING COMPONENTS}

The share of training components in the competitive period

- Physical training: 30\% .- 174 - 180 hours

- Individual technical-tactical training: 35\% - 203 - 210 hours

- Tactical training of 2-3 players and team: $35 \%-203-210$ hours

\section{PERFORMANCE OBJECTIVES}

- Participation in the ONSS National Championship and ranking on a place to qualify for the final tournament.

- Participation in the final tournament and ranking in a pre-arranged place.

- Increasing the effectiveness manifested by achieving at higher parameters the team model of the game and the position model.

\section{Results}

According to the training program for the age of 17-18 years, the content of the program for the age of $15-16$ will be perfected and will be completed with the following:

- The technique of playing with the ball

- Catching the ball with one hand on the spot and away

- Improving the technical procedures in the manifestation of motor qualities, in conditions of adversity and competitiveness

- $5 \times 5$ team tactics

- In attack

- Attack with pivotal players

- Area defense attack
- Pressure zone defense attack

- In defense

- Defense with help and return (against blocking)

- Area defense and pressing area

- Combined defense

- Special attack and defense situations

Table 1

Statistical indicators - Martor group

\begin{tabular}{|c|c|c|c|c|}
\hline & $\begin{array}{c}\text { Specific } \\
\text { test } 1\end{array}$ & $\begin{array}{c}\text { Specific } \\
\text { test } 2\end{array}$ & $\begin{array}{c}\text { Specific } \\
\text { test } 3\end{array}$ \\
\hline \multicolumn{2}{|c|}{ First Test } & 42,5 & 34,5 & 41,66 \\
\hline \multicolumn{2}{|c|}{ Final Test } & 47,5 & 33,5 & 47,5 \\
\hline \multicolumn{5}{|c|}{ Statistic parameters } \\
\hline \multirow[t]{2}{*}{$S$} & $\mathrm{Ti}$ & 6,21 & 0,67 & 7,17 \\
\hline & Tf & 6,21 & 0,67 & 4,52 \\
\hline \multirow[t]{2}{*}{ CV } & $\mathrm{Ti}$ & 14,61 & 1,94 & 17,21 \\
\hline & Tf & 13,07 & 2 & 9,51 \\
\hline \multicolumn{2}{|c|}{ T test } & 1,9722 & 3,6560 & 2,3886 \\
\hline \multicolumn{2}{|l|}{$p$} & 0.0613 & 0,0014 & 0.0260 \\
\hline
\end{tabular}

From the comparative analysis of the averages recorded by the two groups (control and experiment), at the level of 10-12 years we can notice that in the case of specific sample number 1 , in terms of percentage we identify a difference of 30 , and the significance threshold is 0.0001 , which supports the idea that this may be mainly due to the content of the programs proposed by us to the experimental group.

Table 2

Statistical indicators - Experimental group

\begin{tabular}{|c|c|c|c|c|}
\hline & $\begin{array}{l}\text { Specific } \\
\text { test } 1\end{array}$ & $\begin{array}{l}\text { Specific } \\
\text { test } 2\end{array}$ & $\begin{array}{l}\text { Specific } \\
\text { test } 3\end{array}$ \\
\hline \multicolumn{2}{|c|}{ First Test } & 51,66 & 31,66 & 44,16 \\
\hline \multicolumn{2}{|c|}{ Final Test } & 81,66 & 30,41 & 86,66 \\
\hline \multicolumn{5}{|c|}{ Statistic parameters } \\
\hline \multirow[t]{2}{*}{$S$} & $\mathrm{Ti}$ & 6,21 & 0,67 & 7,17 \\
\hline & $\mathrm{Tf}$ & 6,21 & 0,67 & 4,52 \\
\hline \multirow[t]{2}{*}{$\mathrm{CV}$} & $\mathrm{Ti}$ & 14,61 & 1,94 & 17,21 \\
\hline & $\mathrm{Tf}$ & 13,07 & 2 & 9,51 \\
\hline \multicolumn{2}{|c|}{$T$ test } & 4,9722 & 3,6560 & 2,3886 \\
\hline \multicolumn{2}{|l|}{$p$} & 0.0001 & 0,0014 & 0.0260 \\
\hline
\end{tabular}


In the case of the specific sample number 2 we identify a difference of 1.25 , and the significance threshold has a significant value, which supports the idea that this may be due not only to the content of the programs proposed by us.

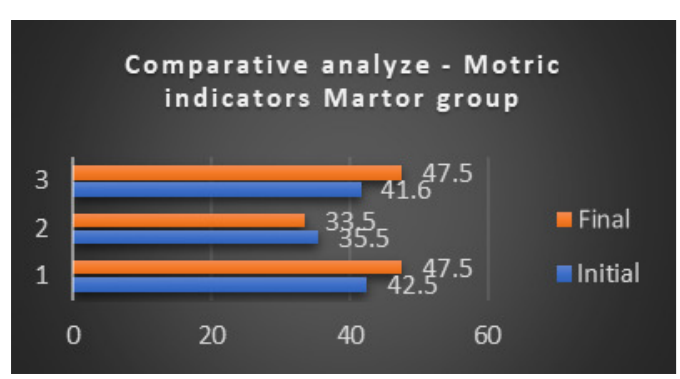

Chart no. 1 - Comparative analysis of specific motor indicators - Control group

From the comparative analysis of the averages recorded by the two groups (control and experiment), we can note that in the case of specific test number 3 in terms of grade, we identify a difference of a significant threshold 0.001 , which reinforces the idea that this is may be mainly due to the content of the programs proposed by us to the experimental group.

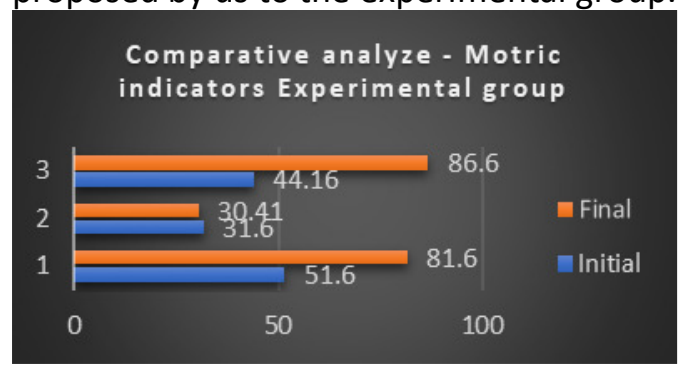

Chart no. 2 - Comparative analysis of specific motor indicators - Experiment group

\section{Conclusions}

1. The high school cycle period is perhaps the most important stage of school physical education, as it develops the components of multilateral physical and technical training, which involves educating at a certain level all motor skills and providing students with a rich motor skills on movement skills. .

2. For the basketball game, this is a stage of consolidation and improvement, a stage in which the fundamental technical-tactical elements are programmed, but also the least accessible (half-hook basket throwing, offered pass, lay-up basket throwing) .

3. Extracurricular activities can be an activity through which, due to the possibilities of organizing the respective school (high school), talented students deepen their training in the game of basketball.

It is organized according to:

- didactic-material basis;

- students skills, inclinations, desires;

- availability and specialization of the teacher;

- financing possibilities;

- school tradition.

4. The content of these training hours is similar to that of the groups of beginners and advanced in sports training and is organized by value training groups, the basic group $\rightarrow$ the representative team.

\section{Motions}

From our point of view, we consider that the basic requirement of performance sports activity at school level, as a echelon of the mass base of performance sports, is the problem of selecting and finding talented students to form the representative team of high school (grades IX - XII ).

We propose that the selection and training of students in the game of basketball is not a momentary action, but an evolutionary process, in which operations take place permanently, even during the preparations. 
The current operation reveals only the availability of the investigated person, materialized in the state of health, general motor behavior and his strong motivation to practice basketball.

An approach is needed in the manner in which the second stage lasts 4-6 weeks, during which the preparation process is combined with the selection process, and depending on the passing of age-specific control tests, students are selected.

We propose that checks be carried out periodically through control tests, the results obtained determine the sorting of students and finally the formation of the group with which the basketball training process actually begins.

A different approach is needed from school sports clubs, the selection at this level is less demanding in terms of the somatic and motor model.

\section{References}

1. Cârstea, Gh.: Teoria si metodica educatiei fizice (Theory and methodology of physical education). Bucharest, Ed. An Da, 2000. p. 28-34

2. Colibaba-Evuleţ, D.: Jocuri sportive Teorie si Metodica (Sports games, theory and methodology). Bucharest, Aldin University Publishing House; 1998, p. 48-51.

3. Colibaba-Evuleţ, D.: Praxiologie si proiectare didactica in educatie fizica si sport (Praxiology and curricular design in physical education and sports). Craipva, Ed. Universitaria Craiova, 2007, p. 33-35.
4. Cojanu, F.: Proiectarea interdisciplinara a lectiei de educatie fizica la ciclul primar (Curricular didactic design in physical education and sports in the primary cycle). Doctoral thesis, University of Piteşti; 2008, p. 28-34.

5. Cojocariu, V.: Teoria si metodologia instruirii (Theory and methodology of training). Bucureşti, E.D.P., 2004, p. 28-33.

6. Coman, S.: Educatia fizica si metodologia predarii (Physical education and the methodology of its teaching in grades I-IV). Iaşi, Ed. Spiru Haret, 1995, p. 55-59.

7. Cucoş, C.: Pedagogie (Pedagogy). Iaşi, Polirom Publishing House, 2002, p. 97-102.

8. Dragomir P., Scarlat E., (2004), Educatie fizica scolara (School physical education), Didactic and Pedagogical Publishing House, Bucharest;p. 65-71

9. Dragnea, A.: Teoria sportului (Theory of Sport). Bucharest, FEST Publishing House, 2002, p. 106-112.

10. Fleancu, L.: Concepte moderne de pregatire fizica la baschetbalistii juniori (Modern concepts of physical training in basketball at the level of junior teams). Craiova, Ed. Universitaria, Craiova; 2007, p. 74-78.

11. National Curriculum for Compulsory Education, (1998), MEN, CNC, Bucharest; 